\title{
DOSSIER VERIFICATION \\ INITIATIVES IN \\ THE SCENARIO OF \\ MISINFORMATION. \\ Actants for integrated plans with multi-level strategies
}

Copyright $\odot 2019$ SBPjor / Associação Brasileira de Pesquisadores em Jornalismo

\section{XOSÉ LÓPEZ-GARCÍA}

Universidade de Santiago de Compostela - Galicia - España ORCID: 0000-0002-1873-8260

ÁNGEL VIZOSO

Universidade de Santiago de Compostela - Galicia - España ORCID: 0000-0001-7898-9267

SARA PÉREZ-SEIJO

Universidade de Santiago de Compostela - Galicia - España

ORCID: 0000-0002-5674-1444

DOI: 10.25200/BJR.v15n3.2019.1215

Received on: 14/03/2019| Approved on: 02/07/2019

\begin{abstract}
The spread of misinformation has become standard practice in today's communicative scene. Both individual users and organizations disseminate false content for economic or political benefits. The response against these strategies has been to develop initiatives to both verify false information as well as prevent it from being spread. This article presents actions adopted by different actors to stop the spread of fake news. These actors are European institutions, national governments, the media, and major technology companies. Thus, this paper takes a comprehensive look at how misinformation is addressed in the European Union by studying reports and legislative texts and reviewing the growth of fact-checking initiatives.
\end{abstract}

Key words: Information verification. Fact-checking. Misinformation. Fake news. Post-truth.

\section{INICIATIVAS DE VERIFICAÇÃO NO CENÁRIO DA DESINFORMAÇÃO. Actantes em planos integrados com estratégias multiníveis}

RESUMO - A disseminação da desinformação se tornou uma prática muito comum no atual cenário comunicativo. Utilizadores individuais e organizações disseminam conteúdo falso para obter benefício econômico ou político. A resposta contra essas estratégias tem sido o desenvolvimento de iniciativas cujo objetivo é tanto a verificação de informações 
falsas quanto a prevenção da sua disseminação. O objetivo deste artigo é mostrar as ações tomadas por diferentes atores com a capacidade de impedir a disseminação de notícias falsas: instituições europeias e governos nacionais, os media e as principais empresas tecnológicas. Assim, através do estudo de relatórios e textos legislativos ou a revisão do crescimento das iniciativas de fact-checking, os autores desenharão uma panorâmica sobre como a desinformação é abordada na União Europeia.

Palavras-chave: Verificação da informação. Fact-checking. Desinformação. Notícias falsas. Pós-verdade.

\section{INICIATIVAS DE VERIFICACIÓN EN EL ESCENARIO DE LA DESINFORMACIÓN. Actantes en planes integrados con estrategias multinivel}

RESUMEN - La propagación de desinformación se ha convertido en una práctica muy frecuente en el escenario comunicativo actual. Usuarios individuales y organizaciones hacen uso de la difusión de contenidos falsos para obtener rendimiento económico o político. La reacción frente a este tipo de estrategias no se ha hecho esperar de forma apareciendo iniciativas dirigidas tanto a la verificación de las informaciones falsas como a evitar su publicación. El objetivo del presente artículo es dar cuenta de las acciones adoptadas por los diferentes actores con capacidad para frenar la difusión de fake news: las instituciones europeas y los gobiernos nacionales, el periodismo y las principales empresas tecnológicas. A partir del estudio de diferentes informes y textos legislativos, así como de las herramientas diseñadas por las empresas tecnológicas o la revisión del crecimiento de iniciativas de fact-checking se dibuja una panorámica general de cómo se intenta combatir la desinformación en el marco de la Unión Europea.

Palabras clave: Verificación de la información. Fact-checking. Desinformación. Noticias falsas Posverdad.

\section{Introduction}

Misinformation is a shadow that has fallen over the communicative landscape of the second decade of this century. Moreover, it has raised concerns in many sectors of civil society, international organizations, non-governmental organizations and some governments. Despite the complexity of anything labelled as post-truth, the fact is that doubts have once again been raised about journalism. Its techniques and methods have been scrutinised and discussed in order to try and define the role it has in complying with public interest. Quality journalism has addressed this challenge by improving verification systems and adding new technologies and modernizing techniques. Fact-checking, along with new professional profiles and multi-disciplinary teams, has strengthened the verification process in order to improve journalistic quality. This line of work is part of a comprehensive approach used to fight misinformation, 
something which is a priority in this day and age and that many reports published by international experts and special committees have addressed over the last few years.

With the general conviction that there is no magical solution and that rash decisions cannot solve this complex phenomenon, it is an integrated approach towards fighting misinformation that has gained importance. Major European institutions and many international organizations have chosen to use this type of model to face this new challenge, and have chosen to collaborate with major actors in communication to face the challenges of misinformation. Organizations in the communication sector - both business groups and professional organizations - play a crucial role in implementing immediate actions and actions for the short and long term. Digital and media literacy are the front-runners for this movement.

The guide of actions against misinformation throughout the world $^{1}$ shows that many steps have been taken recently, including projects for the near future and many references for longer term projects. However, at the moment, there has not been much success in the war against false news. There are some regulations, like in France $^{2}$, which is one of the first countries to push legislation through in this area. There are also some reports and instructions which have been published by international organizations ${ }^{3}$. At any rate, actions that can challenge fake news are just starting to be developed. This concern means all constituents in the communicative landscape are forced to take advantage of the occasion in order to show the strengths of journalism. By admitting the mistakes that have led to some of the biggest false content in recent decades, and with a clear commitment to transparency and more efficient verification systems, journalism will be able to face the challenge that misinformation has posed in our society.

Although this is not an easy challenge for journalism to face, main professional organizations and a number of researchers consider it to be a new challenge, one never seen before in the history of the field. By facing this challenge, journalism will have to reinvent itself and, simultaneously, arm itself with the best methods, techniques and tools for assuring its goal of serving the public interest.

This article is a comprehensive view of the main actions for fighting the proliferation of false information in Europe. In order to achieve this goal, we will review the laws enacted in different countries as well as the verification initiatives that have been used over the 
last few years, and the alert mechanisms designed by technological companies. This review will help us to understand the main decisions adopted by the main actors which are capable of counteracting the proliferation of misinformation.

\section{State of the art}

\subsection{Misinformation as a mechanism throughout history}

Misinformation is now a major element in everyday life. However, it is not particular to now; it has been used continuously throughout history, almost always with the objective of achieving a particular goal by its promoters. We only need to look back to the $4^{\text {th }}$ century, and Procopius Caesarensis, to see that misinformation (and its dissemination) have had a long history. The Byzantine historiographer used false information to discredit the Roman Emperor Justinian by modifying the narration of some chapters of his life (Burkhardt, 2017).

Likewise, the invention of the printing press in the $15^{\text {th }}$ century, and the increasing ease in which content was spread, led to a rise in the circulation of both true and deliberately false information. Different forms of spreading misinformation came about with the emergence of the printing press and its subsequent popularity, increasing its popularity and, as a consequence, the sales of some publications. Clear examples of this can be found with the six-article series published by The New York Sun known as "The Great Moon Hoax". This series described how there was life on the moon, and even included illustrations of creatures that supposedly lived there (Thornton, 2000). Further developments of new forms of communication, like radio and television, continued to keep misinformation alive in people's day to day lives. One of the most recognized examples of spreading false stories was The War of The Worlds radio broadcast, an adaptation narrated by Orson Welles on October 30, 1938. Thousands of listeners initially believed the false information in the live broadcast that an extra-terrestrial invasion was happening at that moment (Gorbach, 2018). Although it was fiction, and not a journalistic story, it is an example that shows the massive potential of mass media and the effect it has on the public when it shares false content. 
Welles' narrative was for the purpose of entertaining. Yet false information and manipulation have been two of the main weapons in many military conflicts over the last two centuries (Tucho, n.d.). False information has been used by many warring factions in order to discredit their enemy, including purposely publishing false images (Bloch, 1999, p. 182). One of the best examples of this was the publication of the explosion of the American battleship, the USS Maine. At the time, the editor of The New York World Joseph Pulitzer) and the editor of the New York Journal (William Randolph Hearst) were in the middle of a sales and popularity war. Randolph sent a correspondent to Cuba to report on the Cuban attack on the American battleship. Although the correspondent had told Randolph that there was no attack, the Journal went ahead and published a series of news report that, despite being false, were also published by many other renowned national newspapers. The story caused huge social unrest, and the government then got involved in a war with Cuba that ended with Cuba gaining its independence (Amorós, 2018 , p. 34). Misinformation was employed in many international conflicts after this war, including both World War I and World War II, the Vietnam War, the Gulf War and, more recently, the Iraq War (Center for Information Technology and Society, 2018; Chomsky \& Ramonet, 1995, p. 8; Peters, 2018).

\subsection{About fake news}

Fake news is a term used to describe articles that appear as though they are real journalistic pieces, but are actually deliberately made to include false elements (Rochlin, 2017). They are produced with the objective to mislead readers (Allcott \& Gentzkow, 2017). Misinformation and fake news have existed as long as real news has (Park, 1940). The current information landscape, with high speed production and consumption of news (Lopez-Borrull et al., 2018), is a breeding ground for misinformation that can easily take part within the collective ideals (Zubiaga et al., 2016).

This scenario, characterised by the development of new technologies and platforms like the Internet and social media, has provided fertile soil for the dissemination of informative content. However, these advancements have also made it easy to disseminate misinformation (Fortis, 2017; Lazer et al., 2018). Social media 
have emerged as some of the biggest distribution channels for misinformation. In recent times, platforms like Facebook or Twitter have become hubs for obtaining information (Bergström \& JervelyckeBelfrage, 2018). Promotors of fake news have taken advantage of the anonymity these online spaces provide to disseminate large amounts of false content (Vosoughi et al., 2018). This has led to a rise in both the dissemination and consumption of misinformation across these platforms, especially in recent years (Waisbord, 2018). The popularity of fake news is so high that it has actually become a business, where the production of false information has resulted in large profits (Kirby, 2016). This is because, sometimes, these false sites (or sites that produce fake news) are able to reach just as many people as legitimate media can (Fletcher et al., 2018).In addition to imitating the formal and visual codes of information published by legitimate media, Marc Amorós (2018, p. 65-66) points out three additional key elements to fake news: a catchy headline, a statement that echoes a reader's opinion, and attempts to look credible by using elements like videos or framed images. These pieces are designed to directly challenge readers' previous beliefs, sometimes taking advantage of the outrage or disagreement that may surround different issues (Rochlin, 2017).

Authors such as Rubin, Chen, and Conroy (2015) highlighted three different types of fake news:

1. Sensationalist news made of unverified and exaggerated headlines made to attract massive audiences through clickbait. 2. Large-scale scandals designed to appear like formal journalistic content. This technique makes it possible to disguise misinformation as real content and make it appear truthful to audiences.

3. Humorous fake news created in the guise of journalistic content. The objective is not to confuse the public, but to make fun of topical issues.

Following a comprehensive study on scientific literature available on misinformation, Tandoc, Lim, and Ling (2018) extended their fake news classification to six types:

1. News satire. This is the most common example, used in spaces and programs of humor.

2. News parody. Some of the characteristics of this typology mirror those of news satire; however, news parody is not based on topical issues, but is instead comprised of fictional elements ad hoc.

3. News fabrication. Content published without any base, trying to imitate information published by legitimate media. This strategy tries to give these news pieces the appearance of being truthful.

4. Photo manipulation. The previous typologies focused mainly on textual content, but this one relates to altering photographs and videos in order to build a fictional reality. 
5. Advertising and Public Relations. Diffusion of advertising content under the appearance of reports about a particular topic. 6. Propaganda. Content made by a political organization to specifically influence the public's perception about that particular organization. It imitates the formal aspect of journalistic pieces.

Economic and ideological motivations seem to be behind these productions. Economically speaking, promoters of fake news web sites make their profits from advertising inserts (Geham, 2017). Ideologically speaking, the dissemination of fake news seems to wear down and undermine political opponents, as described earlier in regard to warring factions (Allcott \& Gentzkow, 2017). Similarly, events like referendums or elections contain some of the highest number of fake news identified over the last few years (Graves, 2016, p. 89; Lowrey, 2017). In addition, some studies have demonstrated the ability of fake news to make specific topics important to the public. Consequently, research conducted by Vargo et al. (2018) has concluded that the verification of fake news by specialized journalists or media have a leverage effect for those topics, becoming increasingly important for audiences.

\subsection{Fact-checking: media response against fake news}

The strategy that media adopted to counteract the growing presence and importance of fake news was to develop practices for verifying information and fact-checking. The objective of this method is "to increase knowledge by reporting and researching the purported facts" (Elizabeth, 2014). All of this is done by correcting major mistakes and mistakes that were previously seen as insignificant (Fole, 2012). Therefore verification, and especially journalists who perform it, act as filters where only data that can be proven makes it to the informative circuit (López-García et al., 2016). Ultimately, when misinformation is spread throughout the public, it is the job of fact-checkers to refute and correct mistakes so as to prevent the public from being subjected to erroneous perceptions (Nyhan \& Reifler, 2010).

One of the first fact-checking references was the specialized website Snopes.com, created in 1995 (Graves, 2016b, p. 28) at a time when online media was becoming popular. Since then, the number of projects which focus exclusively on information verification 
has grown considerably, solidifying fact-checking as a movement to revitalize the ideal of truthfulness, a part of journalism's DNA since its inception (Lim, 2018). At the beginning of 2019, a survey conducted by the University of Duke's Reporters' Lab identified 160 active fact-checking projects throughout the world (Duke Reporters' Lab, 2019). These projects are linked to both established as well as independent media outlets (Cherubini \& Graves, 2016) with multiplatform presence. Lucas Graves (2018) attributes this increase in the number of verification projects to the existence of a transnational movement in journalism that has connected practitioners from many different media systems and journalistic cultures, as well as from different spheres like civil or political.

Many of the currently active projects were developed between 2011 and 2013 (Lowrey, 2017), and conduct most of their activity on the Internet and social media. As discussed earlier, these are the two spaces where misinformation most common occurs. Consequently, information verification must exist in these environments (Currie Sivek \& Bloyd-Peshkin, 2018). This practice is the answer to a quality which is inherent in both fact-checking organizations and professionals; their ability to adapt to a particular context in order to stop the spreading of misinformation (Stencel, 2015).

Thus, the professional profile of fact-checkers is more important than ever. Fact-checkers are journalists whose mission is to clarify false information by checking original sources (Graves, 2016a), a job sometimes performed in groups (Schäfer, 2011). In order to achieve their goal, fact-checkers make use of the most basic rules of journalism. Nevertheless, there are a lot of technological tools designed for analysing and contrasting all types of content — images, videos, databases, and so on (Brandtzaeg et al., 2016). All of these are part of a workflow that, as highlighted by Graves (2018b), is comprised of three phases: false content identification, verification, and correction.

\section{Method}

This project is based on the mixed method. According to Johnson et al. (2007), the mixed method combines both qualitative and quantitative techniques. The first step was to review a number of texts on false content dissemination, verify 
them and the measures taken by different organizations to prevent their dissemination. Data from previous research on the main characteristics of information verification organizations was simultaneously used (Vizoso \& Vázquez-Herrero, 2019). Such data will help us understand the development and current status of fact-checking practices, especially in Europe. As such, the methods used for this study were content analysis and case study for the countries and organizations.

\section{Results}

\subsection{European institutions' response against fake news}

The European information landscape is clearly defined by the high level of importance that the media in each country has for its public. Thus, according to findings from a study released by the Pew Research Center (Mitchell et al., 2018) on eight European countries, which surveyed a total of $69 \%$ of each country's population (the United Kingdom, the Netherlands, Germany, Sweden, Denmark, Spain, France and Italy), at least $75 \%$ of respondents view media outlets as very important or, at least, important in order that their countries run properly. In contrast, according to the Flash Eurobarometer 464: Fake news and disinformation online (Eurobarometer, 2018), 44\% of European citizens consider fake news to be a real problem in their country. This situation is of particular concern in countries like Bulgaria or Cyprus - with a $70 \%$ distrust level — while in countries like Denmark or Luxembourg that level of distrust is around $20 \%$.

Due to the facility in accessing false content and its increased circulation on social media platforms, governments and supranational organizations have a particular interest in stopping its dissemination. Consequently, the European Union has released two reports published in the last two years. Both the European Council (Wardle \& Derakhshan, 2017) and the European Commission (Martens et al., 2018) deliberate over the spread of misinformation and the risks associated with it. These reports are for both internal experts and external consultants, and provide a wide perspective on the issue.

In this regard, the report entitled Information disorder: 
Toward an interdisciplinary framework for research and policy making, published by the European Council, is a collection of thirtyfive recommendations. Their objective is to make main actors aware of their capability to control and reduce the dissemination of fake news. These main actors are technological companies, governments, media outlets, civil society, education ministries, companies and foundations.

The report entitled $A$ multi-dimensional approach to disinformation, prepared by a group of experts from the European Commission in fake news and misinformation, try to design a guideline for those which have the ability to stop misinformation from developing. The guidelines highlighted in this document focus on the need to improve media literacy levels. In this way, social media users would have the tools to be able to distinguish between true and false content. Likewise, this report focuses on the need to increase the level of transparency for the funding of information sources and media outlets in order to eliminate any suspicion of political or corporate interference with their work.

The United Kingdom parliament published the results of its report Disinformation and 'fake news' (House of Commons, 2019) at the beginning of 2019. This document is a reflection on the need for a better understanding of the protocols used by both technological companies and social media platforms for managing information. It is important to understand how these protocols function because most misinformation circulates through spaces controlled by these organizations. This text, like the previously mentioned ones, contains different recommendations from the British Government. These recommendations are to create a code of ethics or a code of good practice for online content. In addition, the report suggests that the creation of an independent regulator, similar to the existing Office of Communications (OFCOM) whose mission is to control and regulate the communication services that citizens use in their daily lives (Ofcom, 2019). This new regulator would regulate and control the circulation of misinformation throughout the United Kingdom.

A report published at the beginning of 2019 by the National Cryptological Centre in Spain, an organization affiliated with the National Intelligence Centre and the Ministry of Defence. This report is both a warning and advice about the dangers of misinformation and its risks to Spanish citizens (Centro Criptológico Nacional, 2019). This text goes over the main characteristics of fake news as well as the particularities of their dissemination. For example, the 
report warns the public about the use of automated tools or the existence of mechanisms utilized by promoters of misinformation that take advantage of the social and legal vulnerabilities. Lastly, this document offers advice on how citizens can avoid being deceived by fake news. Users can do this, for example, by paying attention to the appearance and the content of what is presented as information and disseminated on social media platforms.

If we look at the regulations, there are two European countries that have led the fight against fake news: Germany and France.

The Bundestag (the German federal parliament) passed a law in June 2017 for improving law enforcement in social media called Netzwerkdurchsetzungsgesetz - NetzDG (Bundesministerium der Justiz und für Verbraucherschutz, 2017). This law requires social media platforms to report when they receive more than a hundred complaints about false or illegal content. This law encouraged other technological companies to start using mechanisms for detecting and removing inappropriate content within twenty-four hours of its publication (Claussen, 2018). This German regulation is the first legal step in the fight against misinformation in the European Union.

In France, the Loi relative à la lutte contre la manipulation de l'information (Asemblée Nationale, 2018) came into effect on December $22^{\text {th }}, 2018$. It serves to modify some of the terms from a previous law enacted on September $30^{\text {th }}$, 1986 on the freedom of communication. In addition, this new law includes different features. One of these features is the need for creating mechanisms to combat misinformation from online platform operators, especially for the kind of fake news that could disturb the public order. This was included due to the proliferation of fake news during the 2017 presidential election (Wardle \& Derakhshan, 2017). Furthermore, and like the recommendation published in the United Kingdom, the Conseil supérieur de l'audiovisuel fights against the dissemination of fact news that could affect the normal functioning of electoral processes. If these legal precepts are violated, French law provides for the immediate shutdown of those spaces where false information having a direct and proven influence in the elections was published. 


\subsection{Fact-checking in Europe}

As pointed out in Section 2 (State of the Art), fact-checking is the approach which has been adopted by media to stop the effects produced by the dissemination of misinformation (Geham, 2017). Hence, media outlets and private initiatives around the world have come together to create a movement which has been growing since the first documented initiative was founded - the specialized website Snopes.com, launched in 1995 (Graves, 2016b, p. 28). There are now one hundred and sixty active verification projects (Duke Reporters' Lab, 2019). These initiatives can be independent, be part of a consolidated media group, or be part of legitimate media outlets in the form of an integrated and specialized section.

In the case of the European Union, a Duke Reporters' Lab census from March 2019 identified forty-one regularly active fact-checkers. The number of independent projects is similar to those associated to consolidated brands or media outlets. There are eighteen independent initiatives and twentythree linked to legitimate media outlets. We can see how highly reputable media outlets like the $B B C$ or Le Monde have made clear commitments to this issue with their fact-checking spaces $B B C$ Reality Check (started in 2015) and Les Décodeurs (active since 2012), respectively.

On the other hand, we can also see different verification projects started by civil society organizations through non-profit associations. This is the case of the Austrian Fakt is Fakt or groups of journalists like Croatia's Faktograf or Britain's Full Fact.

The map of fact-checking initiatives in the European Union (Figure 1) shows France as the country with the highest number of active fact-checking projects with seven, followed by the United Kingdom with six working projects, and Germany and Spain with four each. We can find fact-checking initiatives in eighteen out of the twenty-eight European Union countries. Only Belgium, Bulgaria, Cyprus, Slovenia, Finland, Malta, Hungary, Greece, Estonia and Luxembourg did not have any active information verification spaces at the beginning of 2019 . 
Figure 1 - Information verification initiatives in the European Union.

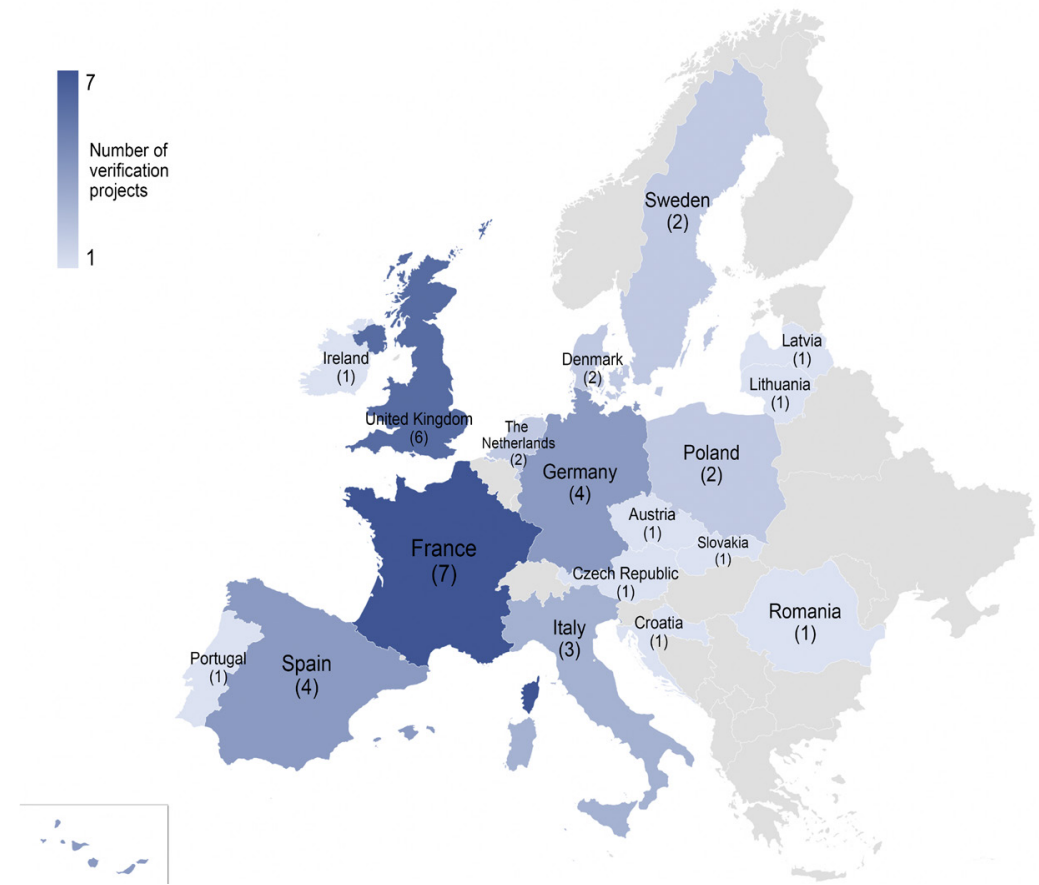

Source: self-made from Duke Reporters' Lab data.

\subsection{Mechanisms for fighting misinformation online}

Although fact-checking was a tool developed by the media to stop the advance of misinformation or, at least, mitigate its effects, there are other actors capable of fighting against the circulation of misinformation. We can see how reports and laws promoted by different European countries and organizations have tried to involve technological companies that control platforms like social media. As we saw in previous sections, these spaces are possibly the focus of spreading false content.

Here we focus on different mechanisms used by technological companies like Google, Facebook, and Twitter to stop the circulation of fake news in their spaces. Their collaboration as well as their decisions are important towards fighting misinformation because they can modify the actions of online content publishers, both truthful or misleading ones (Bell et al., 2017).

Google published its report How Google Fights Disinformation 
(Google, 2019) at the beginning of 2019. This text warns about the dangers and vulnerabilities of the Internet as a consequence of the ease of sharing content online which has very little truth to it or is completely devoid of truth. In this report, the company recognizes that its algorithms cannot determine if a particular content is accurate or not, nor can they understand the intentions of the promoters of said content by detecting it on a website. However, Google explains that they are developing initiatives to detect and hide searches for false information. Thus, the company has stated that it is increasingly easy to identify fact-checkers by looking at their search engine as well as Google News service. Likewise, content published by renowned fact-checking organizations are favoured. The report also points out the need for extreme caution and control when it comes to the dissemination of fake news, especially during electoral campaigns. At the same time, it emphasises the need to constantly recycle and learn about possible new forms and spaces of misinformation.

The social network Facebook has started implementing different tools to help reduce the circulation of fake news on its platform. In 2016, they created a fact-checking initiative together with associations like the International Fact-checking Network, media outlets like The Washington Post and Snopes.com, and the news agency The Associated Press. Thanks to this collaboration, Facebook is able to warn its users of content that media outlets specialized in verification have identified as possibly being false (Wardle \& Derakhshan, 2017).

Another measure taken against misinformation was the closure of more than thirty-thousand automated accounts in France and the United Kingdom adopted by Facebook, just before the elections (Hofileña, 2016). These automated accounts used for spreading misinformation are increasingly frequent and are most effective in the dissemination of rumours, especially those related to candidates in presidential elections in countries like France, the United Kingdom and the United States (Allcott \& Gentzkow, 2017).

In the case of Twitter, automated bots and the ease in which they are programmed pose some of the biggest threats to the integrity of the content published on this platform. Therefore, major modifications in content management for this microblogging platform have focused on trying to control the creation of these automated tools, the function of which is to disseminate a large number of publications in a short period of time. In the last few years, Twitter has implemented different mechanisms for detecting whether content has been published by a bot or not. If the platform detects duplicated 
activity or the massive circulation of content through automated accounts, it starts an investigation. If this massive publication violates Twitter's policy, all its accounts are deleted (Roth, 2018).

\section{Conclusions}

As the review of different documents and initiatives examined in this text has shown, there is a need to stop the circulation of false content. Fake news is a growing reality. National and supranational organizations, as well as companies from both the technological and communicative sector, are trying to work side by side to fight it.

If we look at the European Union, there are not many legislative texts that focus on controlling the circulation of misinformation or that develop sanctions for those who do circulate it. Although some European agencies have established recommendations for trying to stop fake news from being published - especially on the Internet - there is no common regulation applicable to the twenty-eight countries. Thus, only France and Germany have enacted laws useful for identifying, stopping and punishing those with the intention of spreading fake news. The United Kingdom is at a half-way point; although parliament has established a series of recommendations for fighting fake news, they have yet to be passed into law.

Even though these laws were created with the idea of stopping the circulation of false content, and can be an effective measure, legitimate media outlets and other organizations have started a lot of their own information verification or fact-checking initiatives. Their objective is just denying and refuting the falsity of content on the informative circuit. These practices have been introduced in 64\% of European countries (eighteen out of the twenty-eight countries in the EU). Furthermore, the most positive thing about these specialized media outlets is that they have been growing over recent years. Thus, it is possible that many more projects could be created in the years to come, all of them with the objective of correcting misinformation which is accessible by the public. This is happening in an environment where journalistic brands are trying to react to the growing atmosphere of distrust, where citizens have lost some of their trust in legitimate media. Practices like fact-checking are a clear attempt to regain that lost trust.

The third way to reduce the effects of fake news is for platform promoters to establish control mechanisms for the content 
they circulate. As previously noted, most misinformation circulates throughout social media thanks to the enlargement effect of automated systems or bots. Organizations like Google, Facebook or Twitter have admitted that, in recent years, they have adopted different protocols and regulations to try and detect both false content and its origin. If they are unable to discover the origin of the content, social media operators try to at least identify whether said content is questionable. All this is done in order to warn users of potentially false information.

To sum up, thanks to the documentation reviewed for the elaboration of this paper, we can see that collaboration between legislators, technological companies and the media will be one of the keys in the future fight against misinformation or verified facts.

\section{NOTES}

1 The most current updated guide for worldwide actions against misinformation is provided and updated by the Poynter Institute. It is available at: https://www.poynter.org/ifcn/antimisinformation-actions/. Access on: 02/21/2019.

2 French law is from December 2018. Both actions and legislative text are available at: https://www.senat.fr/espace_presse/ actualites/201806/lutte_contre_les_fausses_informations.html

3 There are some reports. We will cite those published by the Council of Europe, the European Commission -from 2018and the United Kingdom Parliament at the beginning of 2019. Council of Europe's report is available at: https://rm.coe.int/ information-disorder-toward-an-interdisciplinary-frameworkfor-researc/168076277c. European Commission report is available at: https://ec.europa.eu/jrc/communities/sites/jrc cties/files/dewp_201802_digital_transformation_of_news_ media_and_the_rise_of_fake_news_final_180418.pdf. United Kingdom Parliament's report is available at: https://publications. parliament.uk/pa/cm201719/cmselect/cmcumeds/363/363.pdf

\section{SUPPORT}

This chapter is prepared within the framework of the project Digital native media in Spain: storytelling formats and mobile strategy (RTI2018-093346-B-C33), from the Ministry of Science, Innovation and Universities (Government of Spain) and is co-funded by the European 
Regional Development Fund (EDRF). This text is also prepared as part of the activities of the Novos Medios Research Group (University of Santiago de Compostela, Gl-1641), supported by the program "Consolidation and Structuration of Competitive Research Units" from the Galician Regional Government (Reference ED431B 2017/48).

Authors Ángel Vizoso and Sara Pérez-Seijo benefit from the University Faculty Training Programme (FPU), financed by the Ministry of Science, Innovation and Universities (Government of Spain).

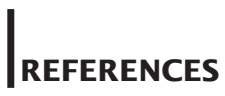

Allcott, H., \& Gentzkow, M. (2017). Social Media and Fake News in the 2016 Election. Journal of Economic Perspectives, 31(2), 21 1-236. DOI: $10.1257 /$ jep.31.2.211

Amorós, M. (2018). Fake News. La verdad de las noticias falsas. Barcelona: Plataforma Editorial.

Bell, E. J., Owen, T., Brown, P. D., Hauka, C., \& Rashidian, N. (2017). The Platform Press: How Silicon Valley Reengineered Journalism. DOI: doi.org/10.7916/D8R216ZZ

Bergström, A., \& Jervelycke-Belfrage, M. (2018). News in Social Media. Digital Journalism, 6(5), 583-598. DOI: $10.1080 / 21670811.2018 .1423625$

Bloch, M. (1999). Historia e historiadores. Madrid: Akal.

Brandtzaeg, P. B., Lüders, M., Spangenberg, J., Rath-Wiggins, L., \& Følstad, A. (2016). Emerging Journalistic Verification Practices Concerning Social Media. Journalism Practice, 10(3), 323-342. DOI: $10.1080 / 17512786.2015 .1020331$

Bundesministerium der Justiz und für Verbraucherschutz. Act to Improve Enforcement of the Law in Social Networks (Network Enforcement Act). , (2017).

Burkhardt, J. M. (2017). Chapter 1. History of Fake News. Library Technology Reports, 53(8), 5-9. Retrieved from https://journals.ala. org/index.php/Itr/article/view/6497

Center for Information Technology and Society. (2018). A Brief History of Fake News. Retrieved from http://www.cits.ucsb.edu/fake-news/ brief-history

Centro Criptológico Nacional. (2019). Desinformación en el 
Ciberespacio. Retrieved from https://www.ccn-cert.cni.es/informes/ informes-ccn-cert-publicos/3552-ccn-cert-bp-13-desinformacion-enel-ciberespacio-1/file.html

Cherubini, F., \& Graves, L. (2016). The Rise of Fact-Checking Sites in Europe. Retrieved from Reuters Institute for the Study of Journalism website: http://reutersinstitute.politics.ox.ac.uk/our-research/risefact-checking-sites-europe

Chomsky, N., \& Ramonet, I. (1995). Cómo nos venden la moto. Barcelona: Icaria.

Claussen, V. (2018). Fighting Hate Speech and Fake News. The Network Enforcement Act (NetzDG) in Germany in the context of European legislation. Rivista Di Diritto Dei Media, 3, 1-27. Retrieved from http://www.medialaws.eu/rivista/fighting-hate-speech-andfake-news-the-network-enforcement-act-netzdg-in-germany-in-thecontext-of-european-legislation/

Currie Sivek, S., \& Bloyd-Peshkin, S. (2018). Where Do Facts Matter? Journalism Practice, 12(4), 400-421. DOI: $10.1080 / 17512786.2017 .1307694$

Duke Reporters' Lab. (2019). Fact-Checking. Retrieved from https:// reporterslab.org/fact-checking/

Elizabeth, J. (2014). Who are you calling a fact checker? American Press Institute. Retrieved from https://www.americanpressinstitute. org/fact-checking-project/fact-checker-definition/

Eurobarometer. (2018). Flash Eurobarometer 464: Fake News and Disinformation Online. In Eurobarometer. Retrieved from http://data. europa.eu/euodp/en/data/dataset/S2183_464_ENG

Fletcher, R., Cornia, A., Graves, L., \& Nielsen, R. K. (2018). Measuring the reach of \&quot;fake news\&quot; and online disinformation in Europe. Retrieved from https://reutersinstitute.politics.ox.ac.uk/our-research/ measuring-reach-fake-news-and-online-disinformation-europe

Fole, X. (2012). Los hechos son sagrados. El fact-checker y la importancia del periodismo. Retrieved from http://www.fronterad. com/?q=hechos-son-sagrados-fact-checker-y-importancia-periodismo

Fortis, B. (2017). Un ejército de fact-checkers le declara la guerra a las noticias falsas. Retrieved from https://ijnet.org/es/blog/un-ejércitode-fact-checkers-le-declara-la-guerra-las-noticias-falsas

Geham, F. (2017). Le fact-checking: une réponse à la crise de l'information et de la démocratie. Retrieved from http://www. fondapol.org/etude/farid-gueham-le-fact-checking-une-reponse-a-lacrise-de-linformation-et-de-la-democratie/ 
Google. (2019). How Google Fights Disinformation. Retrieved from https://www.blog.google/around-the-globe/google-europe/fightingdisinformation-across-our-products/

Gorbach, J. (2018). Not Your Grandpa's Hoax: A Comparative History of Fake News. American Journalism, 35(2), 236-249. DOI: $10.1080 / 08821127.2018 .1457915$

Graves, L. (2016a). Anatomy of a Fact Check: Objective Practice and the Contested Epistemology of Fact Checking. Communication, Culture \& Critique, 10(3), 518-537. DOI: $10.1111 /$ cccr.12163

Graves, L. (2016b). Deciding What's True. New York: Columbia University Press.

Graves, L. (2018a). Boundaries Not Drawn. Journalism Studies, 19(5), 613-631. DOI: 10.1080/1461670X.2016.1196602

Graves, L. (2018b). Understanding the Promise and Limits of Automated Fact-Checking. Retrieved from https://reutersinstitute. politics.ox.ac.uk/our-research/understanding-promise-and-limitsautomated-fact-checking

Hofileña, C. F. (2016). Fake accounts, manufactured reality on social media. Retrieved from https://www.rappler.com/newsbreak/ investigative/148347-fake-accounts-manufactured-reality-social-media

House of Commons. (2019). Disinformation and 'fake news': Final Report. Retrieved from https://publications.parliament.uk/pa/ cm201719/cmselect/cmcumeds/1791/1791.pdf

Johnson, R. B., Onwuegbuzie, A. J., \& Turner, L. A. (2007). Toward a Definition of Mixed Methods Research. Journal of Mixed Methods Research, 1(2), 112-133. DOI: 10.1177/1558689806298224

Kirby, E. J. (2016, December 6). La ciudad europea que hizo una fortuna a base de crear noticias falsas sobre las elecciones de Estados Unidos. BBC News Mundo. Retrieved from https://www.bbc.com/ mundo/noticias-38222222

Lazer, D. M. J., Baum, M. A., Benkler, Y., Berinsky, A. J., Greenhill, K. M., Menczer, F., ... Zittrain, J. L. (2018). The science of fake news. Science, 359(6380), 1094-1096. DOI: 10.1126/science.aao2998

Lim, C. (2018). Checking how fact-checkers check. Research \& Politics, 5(3). DOI 10.1177/2053168018786848

LOI n 2018-1202 du 22 décembre 2018 relative à la lutte contre la manipulation de l’information., Legifrance § (2018).

Lopez-Borrull, A., Vives-Gràcia, J., \& Badell, J.-I. (2018). Fake news, ¿amenaza u oportunidad para los profesionales de la información y la 
documentación? El Profesional de La Información, 27(6), 1346. DOI: 10.3145/epi.2018.nov.17

López García, X., Rodrígues Vázquez, A. I., \& Gromaz, L. A. (2016). Telos. Telos: Cuadernos de Comunicación e Innovación, 103, 74-83. Retrieved from https://telos.fundaciontelefonica.com/archivo/numero103/analisisde-las-experiencias-de-the-washington-post-y-the-guardian/

Lowrey, W. (2017). The Emergence and Development of News Fact-checking Sites. Journalism Studies, 18(3), 376-394. DOI: 10.1080/1461670X.2015.1052537

Martens, B., Aguiar, L., Gómez-Herrera, E., \& Mueller-Langer, F. (2018). The digital transformation of news media and the rise of disinformation and fake news | EU Science Hub. Retrieved from https://ec.europa.eu/jrc/en/publication/eur-scientific-andtechnical-research-reports/digital-transformation-news-media-andrise-disinformation-and-fake-news

Mitchell, A., Simmons, K., Matsa, K. E., Silver, L., Shearer, E., Johnson, C., ... Taylor, K. (2018). In Western Europe, Public Attitudes Toward News Media More Divided by Populist Views Than Left-Right Ideology. Retrieved from http://www.journalism.org/2018/05/14/in-westerneurope-public-attitudes-toward-news-media-more-divided-bypopulist-views-than-left-right-ideology/

Nyhan, B., \& Reifler, J. (2010). When Corrections Fail: The Persistence of Political Misperceptions. Political Behavior, 32(2), 303-330. DOI: 10.1007/s $11109-010-9112-2$

Ofcom. (2019). What is Ofcom? Retrieved February 28, 2019, from Ofcom.org.uk website: https://www.ofcom.org.uk/about-ofcom/ what-is-ofcom

Park, R. (1940). News as a form of knowledge: A chapter in the sociology of knowledge. American Journal of Sociology, 45(5), 669-686.

Peters, M. A. (2018). The information wars, fake news and the end of globalisation. Educational Philosophy and Theory, 50(13), 11611164. DOI: 10.1080/00131857.2017.1417200

Rochlin, N. (2017). Fake news: belief in post-truth. Library Hi Tech, 35(3), 386-392. DOI: 10.1108/LHT-03-2017-0062

Roth, Y. (2018). Automation and the use of multiple accounts. Retrieved from Twitter Blog website: https://blog.twitter.com/developer/en_us/ topics/tips/2018/automation-and-the-use-of-multiple-accounts.html

Rubin, V. L., Chen, Y., \& Conroy, N. J. (2015). Deception detection for news: Three types of fakes. Proceedings of the Association for Information Science and Technology, 52(1), 1-4. DOI: 10.1002/ pra2.2015.145052010083 
Schäfer, M. (2011). Science journalism and fact checking. Journal of Science Communication, 10(4), C02. Retrieved from jcom.sissa.it/ sites/default/files/documents/Jcom 1004(2011)C02.pdf

Stencel, M. (2015). Implications and lessons for journalists practicing fact-checking. Retrieved from https://www.americanpressinstitute. org/publications/reports/survey-research/lessons-journalistspracticing-fact-checking/

Tandoc, E. C., Lim, Z. W., \& Ling, R. (2018). Defining "Fake News." Digital Journalism, 6(2), 137-153. DOI: 10.1080/21670811.2017.1360143

Thornton, B. (2000). The Moon Hoax: Debates About Ethics in 1835 New York Newspapers. Journal of Mass Media Ethics, 15(2), 89-100. DOI: 10.1207/S15327728JMME1502_3

Tucho, F. (n.d.). La manipulación de la información en los conflictos armados: tácticas y estrategias. Retrieved from http://www2.uned. es/ntedu/espanol/novmarcos.htm

Vargo, C. J., Guo, L., \& Amazeen, M. A. (2018). The agenda-setting power of fake news: A big data analysis of the online media landscape from 2014 to 2016. New Media \& Society, 20(5), 2028-2049. DOI: $10.1177 / 1461444817712086$

Vizoso, Á., \& Vázquez-Herrero, J. (2019). Fact-checking platforms in Spanish. Features, organisation and method. Communication \& Society, 32(1), 127-142. DOI: 10.15581/003.32.1.127-142

Vosoughi, S., Roy, D., \& Aral, S. (2018). The spread of true and false news online. Science (New York, N.Y.), 359(6380), 1146-1151. DOI: $10.1126 /$ science.aap9559

Waisbord, S. (2018). Truth is What Happens to News. Journalism Studies, 19(13), 1866-1878. DOI: 10.1080/1461670X.2018.1492881

Wardle, C., \& Derakhshan, H. (2017). Information disorder: Toward an interdisciplinary framework for research and policy making. Retrieved from https://edoc.coe.int/en/media/7495-informationdisorder-toward-an-interdisciplinary-framework-for-research-andpolicy-making.html

Zubiaga, A., Liakata, M., Procter, R., Hoi, G. W. S., \& Tolmie, P. (2016). Analysing How People Orient to and Spread Rumours in Social Media by Looking at Conversational Threads. PLOS ONE, 1 l(3), e0150989. DOI: 10.1371 /journal.pone.0150989 
XOSÉ LÓPEZ-GARCíA. Full Professor of Journalism in the Department of Communication Science at the University of Santiago de Compostela. He has been the coordinator of Novos Medios Research Group since 1994. His research focuses on the study of both online and print media as well as the analysis of the impact of technology on media communication. His contribution in this study was to design the research method, select the documents to be analysed and write both the introduction and the chapter entitled state of the art. E-mail: xose.lopez.garcia@usc.es

ÁNGEL VIzOSO. $\mathrm{He}$ is a researcher at Novos Medios Research Group, University of Santiago de Compostela. His research focuses mainly on the area of information visualization, fact-checking and journalistic production for online media. He has a grant from the Education's University Faculty Training Programme (FPU), financed by the Ministry of Science, Innovation and Universities (Government of Spain). His contribution in this research was to analyse reports and laws as well as analyse the development of fact-checking initiatives in Europe. $\mathrm{He}$ is responsible for writing part of the chapter entitled state of the art, as well as the results and conclusions sections. E-mail: angel.vizoso@usc.es

SARA PÉREZ-SEIJO. She is a researcher at Novos Medios Research Group, University of Santiago de Compostela. Her research focuses mainly on the study of Immersive Journalism, non-fiction video $360^{\circ}$ and Virtual Reality production, and new ways of multimedia and interactive content production for online media. She has a grant from the Education's University Faculty Training Programme (FPU), financed by the Ministry of Science, Innovation and Universities (Government of Spain). Her contribution in this paper was to analyse the results and establish conclusions on the studied topic, as well as help in the writing of the text. E-mail: s.perez.seijo@usc.es 